\title{
Biological fitness at middle-age is reduced in both very lean and obese males
}

\author{
Anna Lipowicz \\ Institute of Anthropology, Polish Academy of Sciences, Kuźnicza 35, 50-951 \\ Wrocław, Poland; E-mail: anna.lipowicz@antro.pan.wroc.pl
}

\begin{abstract}
$A B S T R A C T$ It is a well-documented fact that the relationship between body weight and premature mortality is not linear. Very often it is described as J- or U-shaped. There is solid evidence for strong relationships in adults between obesity (as defined by high values of the body mass index, BMI), mortality, hypertension, cardiovascular disease, stroke, and non-insulin dependent diabetes. However, the opposite end of the BMI distribution (leanness) remains an area of controversy among European populations. Many authors have indicated that leanness elevates the risk of premature mortality, although to a lesser degree than obesity. The aim of this study is to examine whether abnormalities in blood pressure and lung function occur more frequently at both extremes of the BMI distribution than in its middle range.
\end{abstract}

KEY WORDS blood pressure, respiratory indices, J-shaped distribution, BMI Prz. Antropol.-Anthropol. Rev. (2003), vol. 66, pp. 55-63, Figs. 4, Tables 2. ISBN 8386969-92-X, ISSN 0033-2003

\section{Introduction}

Many studies have shown a relationship between body weight and premature mortality. This association has been described as being J-shaped, U-shaped, inverse, positive, or absent [Report of a WHO Expert Committee 1995, KUSHNER 1993, MÅNSSON et al. 1996, ALLISON et al. 1997]. There is solid evidence for strong relationships in adults between obesity (as defined by high values of the body mass index, BMI), mortality, hypertension, cardiovascular disease, stroke, and non-insulin dependent diabetes [JoOs et al. 1984, DONAHUE et al. 1987]. For example, in obese patients from Düsseldorf, Germany, the mortality risk ratio for men with a BMI between 36 and 40 $\mathrm{kg} / \mathrm{m}^{2}$ is 1.50 and for men with BMI equal to or higher than $40 \mathrm{~kg} / \mathrm{m}^{2}$ it is 2.10 , relative to a reference group of a BMI between 25 and 32 [BENDER et al. 1998]. Also, physiological factors increasing the risk of mortality, such as high levels of cholesterol and glucose, are more frequent among obese than normal weight adults [OSTLUND et al. 1990]. 
However, the opposite end of the BMI distribution remains an area of controversy among European populations. Many authors have indicated that leanness elevates the risk of premature mortality, although to a lesser degree than obesity [RHOADS and KAGAN 1983, DORN et al. 1997, THOROGOOD et al. 2003]. The observation that individuals with the lowest relative weights die earlier than individuals with intermediate levels of the BMI, has been questioned. Several authors have expressed doubt about such a relationship and have treated it as an artifact. They have pointed out that cigarette smoking or subclinical diseases could confound the relationship between body weight and mortality because of their direct link with low body weight [MANSON et al. 1995, ALLISON et al. 1997].

The aim of this study is to examine whether abnormalities in blood pressure and lung function occur more frequently at both extremes of the BMI distribution than in its middle range.

\section{Materials and methods}

Between 1982 and 1992, anthropological and medical examinations of 1073 males, 40-50 year-old inhabitants of Wrocław, Poland, were carried out at the Institute of Anthropology, Polish Academy of Sciences, and the Lower Silesian Medical Center, Wrocław. Three social groups of men: professionals, skilled, and unskilled workers were investigated. For the purpose of the present analysis, only men who smoked were chosen.

The following four health-related functional traits were measured: systolic blood pressure SBP $(\mathrm{mmHg})$; diastolic blood pressure DBP $(\mathrm{mm} \mathrm{Hg})$; relative vital capacity RVC (ratio of vital capacity to body height); and forced expiratory volume in $1 \mathrm{sec}$. FEV (ml). Systolic and diastolic blood pressure (SBP, DBP) was measured twice in the sitting position using an MPC-350 apparatus and the two readings averaged for data analyses. Respiratory characteristics were collected using a Collins apparatus, according to standard procedures. Body height and body weight were measured and the body mass index (BMI) was calculated.

The sample was divided into three groups, according to BMI values: (1) lean (BMI equal to or under 20, $N=97$ ); (2) medium (BMI between 20 and 30, $N=867$ ); and (3) obese (BMI over 30, $N=109$ ). The WHO thresholds [Report of a WHO Expert Committee, 1995] were not used in this paper: Among 40-50-year old men, there were not enough lean individuals with a BMI under 18; hence, this threshold was raised to 20. Individuals with grade I of overweight (BMI 25-30) were included in the group with medium weight. It allowed inclusion of the third group only persons with grades II and III of overweight.

Four separate one-way analyses of variance were used to compare healthrelated functional traits of men across the BMI groups. To assess the shape of the analyzed relationship, the values for given characteristics in each group of the BMI were compared with the threshold values (25th or 75 th centile) based on an optimal group. The optimal group was a 25-29-age group of college educated men [ROGUCKA and WELON 1996]. From the biological and medical points of view, 25-29 year-old males 
have reached full physiological maturity and their health-related characteristics have achieved their most favorable values. Next, for each group of men in respect of the characteristics increasing with age (blood pressure), the proportions of men whose values were above the 75th percentile were calculated. For characteristics decreasing with age (respiratory indices), the proportions of men whose values were below the 25 th percentile were calculated. To test the differences between the two proportions, a chi-square test was done.

\section{Analysis}

The results of the four separate oneway analyses of variance are summarized in Table 1. There was a significant correlation between the BMI and three out of four analyzed functional healthrelated traits (systolic blood pressure, diastolic blood pressure, and forced expiratory volume in $1 \mathrm{sec}$.). Relative vital capacity did not show any significant correlation with the body mass index.

The values of the 25 th or the 75 th centile (depending on a negative or a positive linear trend with age) of four functional health-related traits, proportions of lean, medium and obese men (according to the BMI values), and the level of significance of differences in frequencies between the analyzed groups of men are presented in Table 2. The percentage of males with systolic blood pressure exceeding the 75th centile of that trait for young well-educated males $(132.2 \mathrm{~mm}$ $\mathrm{Hg}$ ) was only $38.5 \%$ among the subjects

Table 1. Results of four separate one-way analyses of variance for health-related functional traits of men across the BMI groups

\begin{tabular}{lcc}
\hline Dependent variable & \multicolumn{2}{c}{ Main effect } \\
& $F$ & $p$ \\
\hline Systolic blood pressure (SBP) & 14.84 & 0.000 \\
Diastolic blood pressure (DBP) & 13.65 & 0.000 \\
Forced expiratory volume (FEV) in 1 sec. & 4.95 & 0.007 \\
Relative vital capacity (RVC) & 1.68 & 0.186 \\
\hline
\end{tabular}

Table 2. Proportion of men (aged 40-50) whose values were above the 75th percentile (for SBP and DBP) and below the 25th percentile (for both respiratory indices), based on an optimal group (aged 25-29)

\begin{tabular}{lccccc}
\hline & $\begin{array}{c}\text { Threshold } \\
25 / 75 \text { centile }\end{array}$ & $\begin{array}{c}(1) \\
\text { Lean }\end{array}$ & $\begin{array}{c}(2) \\
\text { Medium }\end{array}$ & $\begin{array}{c}(3) \\
\text { Obese }\end{array}$ & $\begin{array}{c}\text { Significance } \\
\text { between pairs }\end{array}$ \\
\hline SBP & 132.2 & $50.8 \%$ & $38.5 \%$ & $61.7 \%$ & $\begin{array}{l}(1-2)^{*} \\
(2-3)^{* * *}\end{array}$ \\
DBP & 89.8 & $36.9 \%$ & $27.1 \%$ & $48.1 \%$ & $\begin{array}{l}(1-2)^{*} \\
(2-3)^{* * *}\end{array}$ \\
RVC & 24.8 & $70.0 \%$ & $66.5 \%$ & $75.6 \%$ & \\
FEV in 1 sec. & 3687 & $84.4 \%$ & $69.1 \%$ & $76.9 \%$ & $(1-2)^{* * *}$ \\
\hline
\end{tabular}

Level of significance: $* p<0.05 ; * * * p<0.001$ 
with medium values of the BMI, but almost $51 \%$ among the very lean and almost $62 \%$ among the obese ones. A similar pattern occurred when diastolic blood pressure was analyzed. As many as $48.1 \%$ of obese men and $36.9 \%$ of lean men had diastolic blood pressure higher than $89.9 \mathrm{mmHg}$, whereas only $27.1 \%$ of men with medium weight exceeded this value. The percentage of men with relative vital capacity who did not reach the 25th centile for that trait for young well-educated males was $66.5 \%$ among the subjects with medium values of the BMI, whereas it was as much as $70 \%$ among the very lean and $75.6 \%$ among the obese ones. Similarly, the percentage of men with forced expiratory volume in $1 \mathrm{sec}$. who did not reach $3687 \mathrm{ml}$ was $69.1 \%$ among the subjects with medium weight, whereas it reached as much as $84.4 \%$ among the very lean and $76.9 \%$ among the obese ones. The non-linear relationship between the body mass index and functional characteristics is presented graphically in Figures 1-4.

\section{Discussion}

A J-shaped relationship between the BMI and functional characteristics is observed in this study. Among males aged 40-50 and economically active inhabitants of Wrocław, those with BMI between 20 and 30 had the bestfunctioning circulatory and respiratory systems. Extreme fatness and extreme leanness were both associated with an impaired function of these systems. Men with BMI equal to or under 20 , and men with BMI over 30 achieved higher values of systolic and diastolic blood pressure and lower values of forced expiratory volume in $1 \mathrm{sec}$. Only relative vital capacity did not exhibit such a relationship.

A number of empirical studies have shown that a similar pattern occurred when the association between mortality ratios and BMI values was analyzed. DORN et al. [1997] investigated the long-term relation between the body mass index and mortality among men and women aged 20-96 in the Buffalo Blood Pressure Study. A significant linear association was found between the BMI and all-cause mortality in men under 65 years old, but not in women. In men aged 65 and older, the relation was quadratic in form $(p=0.02)$, with the lowest risks appearing in a BMI range of 23-27. RHOADS and KAGAN [1983] found that among 45-68 year-old Honolulu Japanese men that mortality was highest in both the leanest and fattest men and lowest in the fourth quintile of the body mass index. An excess of deaths in the top quintile was caused primarily by coronary heart disease (CHD), whereas in the bottom two quintiles the excess deaths were due to cancer and "other" causes. In addition, in an unusually slim group of non-meat eaters from the United Kingdom, participants with a BMI below 18 had an increased all cause death ratio and increased ratios of death from circulatory and respiratory diseases [THOROGOOD et al. 2003].

Several authors have suggested that the relation described above is an artifact and that the increased risk of mortality at low BMI values is not real. In this context two confounding variables were mentioned: effects of the smoking habit, and pre-existing diseases. It is a well-known fact that cigarette smoking 


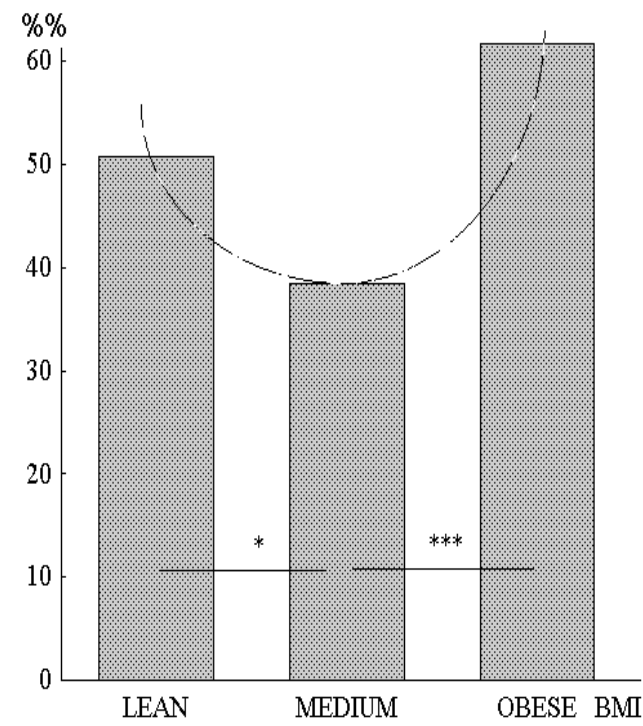

Fig 1. The proportion of males with systolic blood pressure exceeding the 75th centile, based on optimal group.

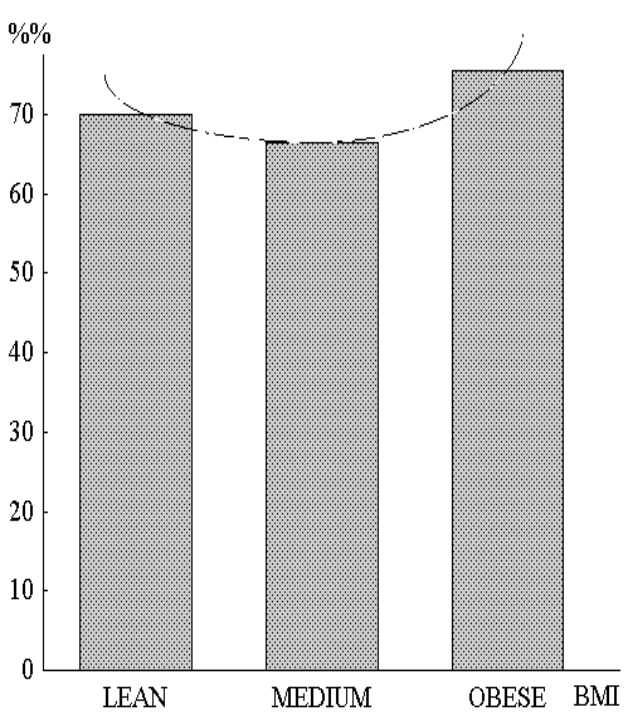

Fig. 3. The proportion of males with relative vital capacity below the 25 th centile, based on optimal group.

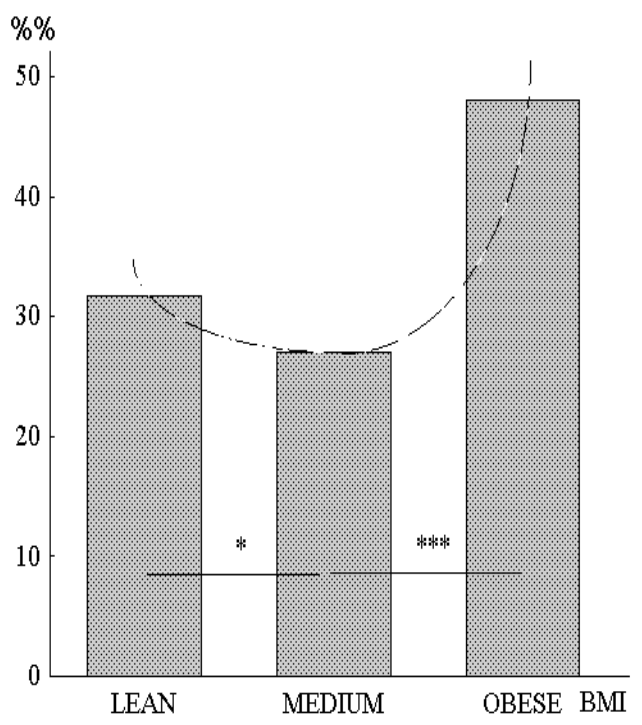

Fig. 2. The proportion of males with diastolic blood pressure exceeding the 75th centile, based on optimal group.

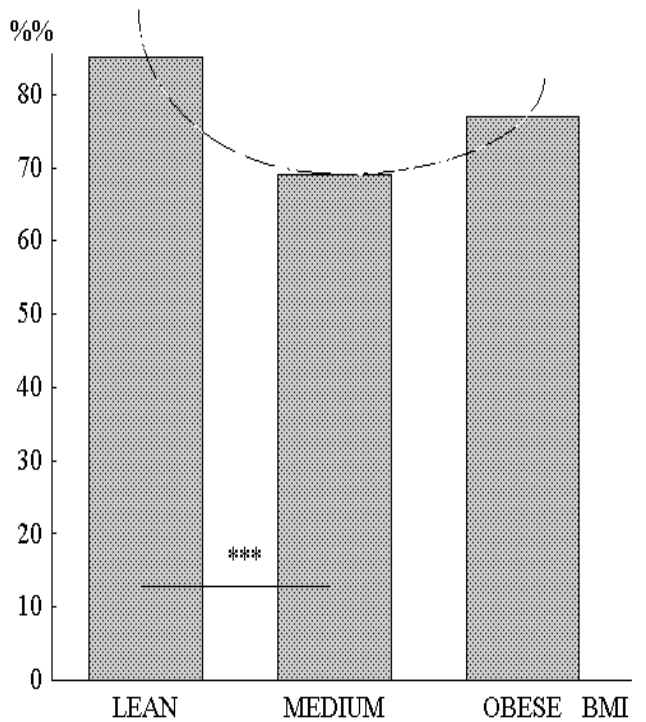

Fig. 4. The proportion of males with forced expiratory volume in $1 \mathrm{sec}$. below the 25 th centile, based on optimal group. 
is responsible for both low body weight, due to suppression of appetite and increasing body metabolic rates [HICKEY and MULCAHY 1973, HOFSTETTER et al. 1986], and for higher mortality rates [WYNDER and HOFFMANN 1967, DOLL and PETO 1981]. MANSON et al. [1995] found that a J-shaped association between the BMI and overall mortality existed among women aged 30-55. However, when women who had never smoked were examined separately, the J-shaped association disappeared. It remained only among formerly and currently smoking women. Furthermore, in the case of pre-existing diseases, when loss of weight is often a symptom of an early death, the exclusion from longterm analysis of subjects who had died during the first several years caused the disappearance of the $\mathrm{J}$ - or U-shaped association.

MANSON et al. [1995] claimed that excess risks of mortality associated with leanness in their study were artifactual and were therefore eliminated after accounting for cigarette smoking and subclinical disease. However, many studies controlling these confounders [RISSANEN et al. 1989, FOLSOM et al. 1993, SINGH et al. 1999, MEYER et al. 2002] still show the J- or U-shaped relation. SINGH et al. [1999] found a J-shaped relation between body weight and mortality among older women who had not undergone postmenopausal hormone replacement. Next, MEYER et al. [2002] suggested that a J-shaped association between the BMI and total mortality existed even when smoking habits and physical activity were analyzed. MÅNSSON et al. [1996] examined adult males from Malmö, Sweden, and found that among under- and overweight, especially the obese, a high proportion of males were on disability pensions. After adjustment for smoking, there was still a J-shaped relation between the body mass index and the incidence of disability pensions. The relative risk (with a group of normal BMI as reference) among underweight men was 1.9, for the overweight subjects -1.3 and for the obese -2.8 , all differences being significant. After adjustment for hypertension, these results persisted, although slightly weakened. The high pension rate among the obese men was mainly a result of diseases of the circulatory and musculoskeletal systems (diseases of muscles and connective tissue). Among lean men, the disability pension was granted primarily because of alcohol dependence and diseases of the musculoskeletal system (collagenoses, including rheumatoid arthritis and diseases of muscles and connective tissue).

ALLISON et al. [1997] presented an additional hypothesis to explain the Uor J-shaped relation between the BMI and mortality. The elevated risk of mortality at the low end of the BMI distribution may be due to a measurement problem, namely the use of the BMI as a measure of "adiposity". These authors suggested that this relation might result from the fact that the BMI is composed of separate components, mainly fat mass (FM) and fat-free mass (FFM), which have opposite effects on health and longevity. Increasing amounts of FM pose a threat to health [STEVENS and MARQUIS 1996], while increasing amounts of FFM enhance it [SHEPHARD 1994]. At the same time BERGMAN and ROGUCKA [1998] found that for men aged 40-50 the correlation between the BMI and other mea- 
surements of fatness (e.g., the sum of skinfolds, impedance) was higher for lean persons (BMI equal to or under 24) than for obese ones (BMI equal to or over 27).

In conclusion, the BMI is a good indicator of the risk of morbidity and mortality, at least in middle-aged adults. In many populations the J- or U-shaped relationship between relative weight and all-cause mortality has been reported. It is assumed that causes of death associated with a low BMI are tuberculosis, obstructive lung disease, and cancer of the lung and stomach; whereas those associated with a high BMI are cerebrovascular disease, cardiovascular disease, diabetes and, in men, colon cancer [Report of a WHO Expert Committee, 1995]. Few explanations for such a pattern are offered (from artifact to behavioral reasons), but none explains the problem satisfactorily. In this study, among males aged 40-50, both obesity and extreme leanness were associated with an impaired function of the circulatory and respiratory systems. It reflects the J- or U-shaped relationship between body weight and mortality.

\section{References}

Allison D.B., M.S. Faith, M. HeO, D.P. KOTLER, 1997, Hypothesis concerning the $U$-shaped relation between body mass index and mortality, Am. J. Epidemiol., 146, 339-49

Bender R., C. Trautner, M. Spraul, M. Berger, 1998, Assessment of excess mortality in obesity, Am. J. Epidemiol., 147, 42-48

BERGMAN P., E. ROGUCKA, 1981, Interkorelacje różnych miar ottuszczenia ogólnego i dystrybucji thuszczu u dorostych mężczyzn i kobiet, Wych. Fiz. Sport, 3, 79-91

Doll R., R. PETO, 1981, The causes of cancer, quantitative estimates of avoidable risk of can- cer in the United States today, Oxford University Press, Oxford

Donahue R.P., R.D. Авbot, E. Bloom, D.M. REeD, K. YANO, 1987, Central obesity and coronary heart disease in men, Lancet, 1, 82124

DORN J.M., E.F. SCHISTERMAN, W. WINKELSTEIN JR., M. TrevisAn, 1997, Body mass index and mortality in a general population sample of men and women, Am. J. Epidemiol., 146, 919-31

Folsom A.R., S.A. Kaye, T.A. Sellers, C.P. Hong, J.R. CERHAN, J.D. POTTER, R.J. PrINEAS, 1993, Body fat distribution and 5-year risk of death in older women, J. Am. Med. Assoc., 269, 483-87

HiCKEy N., R. MulCAHY, 1973, Effect of cessation of smoking on body weight after myocardial infraction, Amer. J. Clin. Nutr., 26, 383-87

Hofstetter A., Y. Schultz, E. Jequier, J. WAHREN, 1986, Increased 24-hour energy expenditure in cigarette smokers, N. Engl. J. Med., 314, 79-82

Joos S.K., W.H. Mueller, G.L. Hanis, W.J. SCHULL, 1984, The diabetes alert study: Weight history and upper body obesity in diabetic and non-diabetic Mexican-American adults, Ann. Hum. Biol., 11, 167-71

KUSHNER R.F., 1993, Body weight and mortality, Nutrition Reviews, 51, 127-36

Manson J.E., W.C. Willett, M.J. StampFer, G.A. Colditz, D.J. HunTer, S.E. Hankinson, C.H. Hennekens, F.E. Speizer, 1995, Body weight and mortality among women, N. Engl. J. Med., 333, 677-85

MÅnSSON N.O., K.F. ERIKSSON, B. ISRAELSSON, J. Ranstam, A. Melander, L. RÅstam, 1996, Body mass index and disability pension in middle-aged men - non-linear relations, Int. J. Epidemiol., 25, 80-85

Meyer H.E., A.J. SogaArd, A. Trevdal, R.M. SElmer, 2002, Body mass index and mortality: The influence of physical activity and smoking, Medicine and Science in Sports and Exercise, 34, 1065-70

OstLund R.E., M. STATEN, W.M. Kohrt, J. Schultz, M. Malley, 1990, The ratio of waist-to-hip circumference, plasma insulin level, and glucose intolerance as independent predictors of the HDL2 cholesterol level in older adults, N. Engl. J. Med., 322, 229-34 
Report of a WHO Expert Committee, 1995 , Physical status: The use and interpretation of anthropometry, WHO Technical Report Series 854, Geneva

RhOADS G.G., A. Kagan, 1983, The relation of coronary disease, stroke, and mortality to weight in youth and in middle age, Lancet, $\mathbf{1}$, 492-95

Rissanen A., M. Heliovaara, P. Knekt, A. AromaA, A. Reunanen, J. MaAtela, 1989, Weight and mortality in Finnish men, J. Clin. Epidemiol., 42, 781-89

Rogucka E., Z. Welon, 1996, Fitness of professionals and skilled workers in Poland, J. Biosoc. Sci., 28, 161-76

SHEPHARD R.J., 1994, Physical activity and reduction of health risks: How far are the bene- fits independent of fat loss? Journal of Sports Medicine and Physical Fitness, 34, 91-98

SingH P.N., K.D. LundSTED, G.E. FrASER, 1999, Body weight and mortality among adults who never smoked, Am. J. Epidemiol., 150, 1152-64

SteVens J., J.C. MARQUIS, 1996, Weight changes prior to baseline in participants who die within the first five years of follow-up (abstract), Obes. Res., 4 (suppl. 1), p. 12

Thorogood M., P.N. Appleby, T.J. Key, J. MANN, 2003, Relation between body mass index and mortality in an unusually slim cohort, J. Epidemiol. Comm. Health, 57, 130-33

WyNDER E.L., D. HofFMAnN, 1967, Tobacco and Tobacco Smoking, Academic Press, New York

\section{Streszczenie}

Wiele badań nad związkiem przedwczesnej umieralności i masy ciała wskazuje na istnienie J- lub U-kształtnej zależności. Podczas gdy zwiększona umieralność oraz zachorowalność wśród osób otyłych jest dobrze udokumentowana, to pytanie czy zależność ta dotyczy również osób bardzo szczupłych, wciąż budzi wiele kontrowersji. Wielu autorów dowodzi, że nadmierna szczupłość ciała również podwyższa ryzyko przedwczesnej śmierci, choć w mniejszym stopniu niż otyłość. Celem tego badania jest odpowiedź na pytanie, czy nieprawidłowości w funkcjonowaniu układu krwionośnego oraz układu oddechowego, pojawiają się częściej na obu końcach rozkładu względnej masy ciała (BMI), a więc wśród osób otyłych i bardzo szczupłych, niż wśród osób o średniej masie ciała.

Analizę oparto na danych pomiarowych 1073 mężczyzn, 40-50-letnich, aktywnych zawodowo mieszkańców Wrocławia palących tytoń. Do oceny stanu układu krążenia użyto skurczowego i rozkurczowego ciśnienia krwi; do oceny stanu układu oddechowego wykorzystano względną pojemność życiową płuc (pojemność życiowa płuc/wysokość ciała) oraz jednosekundową pojemność wydechową płuc. Badanych mężczyzn podzielono na trzy grupy: szczupłych (BMI $\leq 20, N=97)$; o średniej masie ciała $(20<\mathrm{BMI} \leq 30, N=867)$ oraz otyłych $(\mathrm{BMI}>30, N=109)$. W celu porównania wartości poszczególnych analizowanych zmiennych w trzech wyróżnionych ze względu na BMI grupach mężczyzn zastosowano cztery oddzielne jednoczynnikowe analizy wariancji. Wyniki poszczególnych ANOVA zawiera Tab. 1. Trzy spośród czterech analizowanych zmiennych wykazały istotną zależność od BMI (skurczowe ciśnienie krwi: $F=14,84 ; p=0,000$; rozkurczowe ciśnienie krwi: $F=13,65 ; \quad p=0,000 ;$ oraz jednosekundowa pojemność wydechowa płuc: $F=4,95$; $p=0,007)$. Względna pojemność życiowa płuc nie wykazała istotnej zależności od BMI.

Następnie dla każdego analizowanego parametru układu krążenia i oddechowego, obliczona została wartość graniczna, od której możemy mówić o nieprawidłowości. Dla cech, których wartości wzrastaja z wiekiem (ciśnienie krwi) jest to 75 centyl, natomiast dla cech, których wartości obniżają się wraz z wiekiem (parametry oddechowe) - 25 centyl, wyliczony z rozkładu danej cechy w populacji zdrowych, 25-29 letnich mężczyzn z wyższym wykształceniem. W każdej z trzech grup mężczyzn, obliczono procentowy udział osób, przekraczają- 
cych (lub nie osiagających) określone wartości graniczne analizowanych parametrów. Poszczególne wartości graniczne oraz częstości mężczyzn pozostających poza tymi granicami zawiera Tab. 2. Wśród mężczyzn ze średnią masą ciała tylko $38,5 \%$ posiadało ciśnienie skurczowe krwi powyżej 132,2 mmHg, podczas gdy wśród otyłych, takich osób było aż $61,7 \%$, a wśród bardzo szczupłych 50,8\%. Podobnie było w przypadku ciśnienia rozkurczowego krwi: $48,1 \%$ otyłych i $36,9 \%$ szczupłych badanych miało ciśnienie rozkurczowe krwi powyżej $89,9 \mathrm{mmHg}$, podczas gdy tylko $27,1 \%$ mężczyzn ze średnią masą ciała osiagnęło wartość graniczną tego parametru. Podobna zależność widoczna była w przypadku parametrów oddechowych. Wśród mężczyzn z normalną masą ciała $66,5 \%$ miało relatywną pojemność życiową płuc poniżej wartości 24,8 , podczas gdy wśród otyłych 75,6\%, a wśród szczupłych $-70,0 \%$ nie osiagnęło wartości progowej dla tej cechy (różnice nieistotne statystycznie - patrz Tab. 2). Ponadto 69,1\% mężczyzn ze średnią masą ciała miało jednosekundową pojemność wydechową płuc poniżej wyznaczonego poziomu progowego wynoszącego $3687 \mathrm{ml}$, podczas gdy wśród otyłych było 76,9\%, a wśród szczupłych - aż 84,4\% takich osób. Rys. 1-4 przedstawiają powyższe zależności w sposób graficzny.

Przedstawione wyniki jednoznacznie wskazują na istnienie J-kształtnej zależności pomiędzy masą ciała a parametrami układu krążenia i układu oddechowego, gdzie zarówno otyłość $($ BMI > 30) jak i nadmierna szczupłość ciała $(B M I \leq 20)$ upośledza funkcjonowanie organizmu mężczyzn w wieku 40-50 lat. Odzwierciedleniem tego jest taka sama zależność umieralności od względnej masy ciała. Powstało kilka prac, których autorzy starają się wyjaśnić tę zależność (od artefaktu do przyczyn związanych ze stylem życia), jednakże żadna z nich nie tłumaczy ich w pełni satysfakcjonująco. 